\title{
Process innovation costs in supply networks: a synthesis
}

\author{
Raluca Bunduchi * \\ Lecturer in Management, \\ University of Aberdeen Business School
}

Edward Wright Building, Dunbar Street, Aberdeen, AB24 3QY, Tel: 0044 (0) 1224273318; Fax: 0044 (0) 122427 2181; e-mail: r.bunduchi@abdn.ac.uk

\author{
Alison U. Smart \\ Senior Lecturer in Management \\ University of Aberdeen Business School
}

Edward Wright Building, Dunbar Street, Aberdeen, AB24 3QY, Tel: 0044 (0) 1224272261; Fax: 0044 (0) 122427 2181; e-mail: alison.smart@abdn.ac.uk 


\title{
Process innovation costs in supply networks: a synthesis
}

\begin{abstract}
This paper provides a synthesis of the literature on the costs incurred by organizations that develop, adopt, and use interorganizational process innovations in supply networks. A review of the literature in this area suggests that innovation costs influence the pattern of adoption. There is, however, a lack of consensus about what these innovation costs entail. Based on a review of innovation literature in the area of information systems this paper develops an integrative framework of interorganizational process innovation costs. The framework identifies six broad categories of costs (both tangible and intangible) that map onto different stages of organizational innovation: development and initiation costs associated with the generation of an innovation; switching costs and the cost of capital associated with the acceptance stage; and implementation and relational costs associated with implementation. The framework serves not only to organize existing literature and but also to provide the impetus for future research into the role that different categories of costs play in shaping interorganizational process innovation in supply networks.
\end{abstract}




\section{Introduction}

The study of the development, adoption and use of innovations has long been of interest to scholars from a wide range of disciplines (Farrell and Saloner 1985; Rogers 1995; Thompson 1965; Utterback and Abernathy 1975; Zmud 1982). The adoption of innovations has been conceptualised either as a process of communication, where the pattern of adoption reflects the pattern of information flow about the innovation, or as a process of individual decision making, where the pattern of adoption is determined by the profitability of adopting an innovation (Attewell 1992). Both conceptualisations have informed the study of innovation (Attewell 1992) and a great deal of effort has been devoted to identifying the factors that influence the adoption and use of innovation in organizations. This paper focuses on one of these factors: innovation cost. There are three reasons for this focus. Firstly, existing literature has shown that innovation costs play a significant role in shaping the innovation process. For example, the cost of technology acquisition and the cost of capital have been found to be significant impediments to the adoption of advance technologies in the manufacturing sector (Baldwin and Lin 2002). Research has also found that developing a value proposition that clarifies the costs (and benefits) associated with investment in innovation enables organizations to exploit technological innovations successfully (Chatterjee et al. 2002). Secondly, current innovation research fails to recognise the complexity of the cost variable. In most instances cost is considered as a single, high-level variable that gives only a partial representation of the total cost. For example, Chwelos et al. (2001) consider the "the financial costs of developing and implementing" an electronic data interchange (EDI) system, Attewell (1992) discusses the cost of equipment, and Farrell and Shapiro (1988) concentrate on 
switching costs. While considerable attention has been paid to identifying the different types of benefits that accrue to organizations that adopt innovation (see for example the studies of Chwelos et al. 2001; Iacovou et al. 2006; and Mukhopadhyay et al. 1995 in the information systems innovation literature), no attempt has been made to identify and synthesize the different costs into a single coherent framework. For this reason we focus on the costs, rather than on the benefits of innovation. In doing so, we are not attempting to downgrade the importance of benefits, but recognize that considering the two in a single paper will make this paper unwieldy. Thirdly, organizational innovation occurs in stages (Thompson 1965). While existing literature has analysed the different activities involved in the various stages of the organizational innovation process (Cooper and Zmud 1990; Damanpour and Schneider 2006; Kwon and Zmud 1987; Pierce and Delbecq 1977) no attempts have been made to apportion costs to different stages. There is no directing and organizing framework to facilitate an understanding of the costs that arise during the innovation process.

The purpose of this paper is to develop a framework that clarifies the different types of costs that organizations incur during the lifetime of an innovation. In doing this we have been guided by the research question: "What costs are incurred by organizations during the different stages of the organizational innovation process?" To address this question we have employed a literature survey.

The framework developed in this paper focuses on interorganizational process innovation in the supply network context. In selecting a clearly defined innovation area, that of supply networks, we address the criticism levelled at much of innovation research (Zmud 1982) that it neglects the context in which innovation takes place. 
Companies operate in business networks (Wilkinson and Young 2002) in an environment in which the activities of agents beyond the boundaries of the focal organization can have an impact on the success or failure of the organization. Supply networks have become the focus of much research, particularly in the last decade, as it has been recognized that organizations develop tight networks of inter-organizational links that are increasingly seen as the locus for innovation and value creation (Edwards et al. 2004). Supply networks have been defined as 'interconnected entities whose primary purpose is the procurement, use, and transformation of resources to provide packages of goods and services' (Harland et al. 2001 p. 22). Network participants are linked through the receipt of orders and the transmission of goods or services. Increasingly, members of supply networks interact through information technology applications, and notably through interorganizational information systems.

In discussing interorganizational process innovations we are specifically referring to those innovations, almost exclusively in the form of information systems, which transcend organizational boundaries and which aim to improve processes at the interfaces of different organizations within supply networks. For example interorganizational information systems such as EDI systems and web-based ordering systems are used to facilitate transactions between organizations within supply networks and to ensure that the maximum value is extracted by automating routine transactions. Track and trace technologies such as radio frequency identification (RFID) technologies are used to support logistics management. Because of the dominance that interorganizational information systems have acquired in supporting interorganizational processes within supply networks we draw primarily on the information systems literature in our review to inform the development of a 
framework of costs associated with inter-organisational process innovation.

Our review of the innovation costs during the different stages of organizational innovation process contributes to developing a better understanding of the factors shaping organizational innovation processes over time. A granular approach to studying innovation costs is also of benefit to practitioners as it helps to clarify the cost inputs into the innovation cost-benefit analysis.

The paper is divided into four sections. We begin by describing the methods employed during our literature review process. This is followed by a review of the existing literature that has sought to analyse and measure the costs associated with innovation adoption and to assess the influence that these costs have on the likelihood of adoption. The next section draws on these studies to develop a framework that builds a typology of the different categories of costs associated with interorganizational process innovation during the different stages of the organizational innovation process. The paper concludes by discussing the implications of the study for practice and for research.

\section{Methodology}

Articles for inclusion in the literature review were first identified by carrying out database searches using the key words interorganizational, innovation, cost, and information system. Initially the search focused on the information systems literature as representing the most likely source of material on interorganizational process innovations. We used two databases, ABI Inform (Proquest) and JSTOR (limiting the search to business, economics, finance and sociology journals) to ensure coverage of the information systems, supply chain and economics literatures. The searches 
included full text and were limited to scholarly articles only. The initial searches yielded 1,640 titles. The titles were screened to identify those that related to information technology adoption and cost (many articles could be excluded simply by reading their titles, which clearly indicated that the focus of articles did not relate to mainstream management in general and technology adoption in particular). If there was some doubt the abstracts were skimmed to check if the article considered costs of adoption. This process yielded fifty-two abstracts for detailed reading. From detailed reading of the abstracts twenty-two initial articles were identified for full reading. Articles which discussed costs only in the broadest terms when considering technology acquisition were not included among the articles selected for in depth reading if the authors treated cost indirectly as a part of a different construct (including terms such as "organizational readiness" or "relative advantage") or if the costs were simply included as a single high level variable ("the financial costs of adoption and use"). Case studies of technology acquisition where costs were specific to the technology and where no specific break down of cost could be identified were also excluded at this stage, as were articles where the cost variable was not clearly explained. This left articles where the authors included a finer-grained categorization of the costs associated with innovation or where they looked specifically at a particular category of adoption costs and/or the impact of costs during the different innovation adoption stages. Restricting the focus of the work to articles in which authors attempted to give a more granular view of costs is in line with our research objective to identify the different categories of costs and their impact on innovation process.

We then adopted a snowball approach, reading articles referenced as referring to cost 
within the papers initially identified. This was necessary for two reasons. Firstly, some articles referred to specific types of cost, but did not explain the costs precisely. For example, Zhu et al. (2006) identify switching costs as a critical variable influencing process technology adoption but do not precisely define the nature of the switching costs involved, referring simply to articles in the economics literature, notably Klemperer $(1987 ; 1995)$. To clarify the different types of switching costs we therefore looked at the economics literature (for example the works by Klemperer, Farrell and Saloner (1988) and Tang and Zannetos (1992)). In doing this we kept in mind Tranfield et al.'s (2003) argument that “...studies need to consider crossdisciplinary perspectives and alternative ways in which a research topic has been tackled" (p. 214). Secondly, some of the articles referred to material that had not been identified in the initial search and which provided additional, or even a fuller, explanation of costs. This process added eight articles to the twenty-two originally identified in the information systems literature.

Articles were read by both co-authors independently to identify the cost types and we then placed these types into broad categories. The types were refined gradually as more articles were identified. We started with only three broad categories of costs: development, acceptance and implementation. As we were conducting the review, we identified different subcategories; for example, we differentiated between internal and external development costs. The refinement of the cost types continued until all the costs identified in the articles could be fitted under the headings included in the framework. 


\section{The cost of innovation adoption}

\section{Cost versus benefit}

The process of organizational innovation is shaped by both innovation costs and innovation benefits. For example, the perceived net benefit offered by an innovation has been shown to influence organizational adoption (Mansfield 1993). While this net benefit implicitly includes innovation costs, most research has focused on clarifying the different types of benefits (Johnston and Vitale 1988), rather than on examining the cost construct. A brief search of the literature on interorganizational process innovation revealed several studies that analyse the impact of perceived benefits on innovation adoption as a disaggregated and well developed construct (see Table 1).

\section{Insert Table 1 about here}

In contrast, the impact of innovation costs on organizational adoption is generally studied with cost considered only as a single construct. For example, in their model of EDI adoption, Chwelos et al. (2001) identify seventeen different types of perceived benefits associated with EDI adoption (p. 319) while costs are simply measured as the perceived direct financial costs associated with EDI adoption and use. Similarly, in their research measuring the adoption of EDI on small organizations, Iacovou et al. (1995) include eight categories of perceived benefits; in contrast, costs are measured as part of a general construct 'organizational readiness for EDI', and are simply shown as installation and integration costs. Relatively few studies (Premkumar et al. 1994; Zhu et al. 2006) include a detailed analysis of innovation costs as an explicit factor shaping adoption. This is unsurprising given that costs are generally considered to be easier to calculate than benefits (Irani et al. 1997; Tornatzky and Klein 1982). 
In assessing the business value associated with EDI adoption, Mukhopadhyay et al. (1995) argue that while "the stream of costs over time can be identified, the incidence of benefits over time is harder to quantify" (p. 150). Researchers have focused on what has been perceived as the difficult task of identifying and measuring different benefits of innovation and their impact on innovation adoption, rather than on the relatively 'easy' task of accounting for the costs. However, as Irani et al. argue, "[t]he costs of IT/IS often appear more tangible in nature because the assumptions and dependencies on which they are based are often not fully acknowledged, or are poorly understood" (p. 700).

It also can be argued that for some technologies, innovation costs are not important in determining diffusion and adoption. For consumer product innovations such as the iPod, where adopting an innovation is likely to provide a perceived social advantage, users are unlikely to be sensitive to price. Indeed, a cheap product might be less attractive to adopters, who feel that the social cachet associated with the product would be compromised by it being available to all. However, innovation costs have been found to be a significant factor in shaping the adoption of interorganizational process innovations. For example, the financial costs associated with the development and implementation of EDI systems have been shown to influence the intent to adopt EDI (Chwelos et al. 2001; Premkumar et al. 1994). The influence of these perceived financial costs on adoption was found to be even greater than that of the perceived benefits (Chwelos et al. 2001). Similar results have been found for the adoption of open standard interorganizational information systems, for which adoption costs were shown to be significant drivers of adoption (Zhu et al. 2006). 
The importance of innovation costs in explaining the adoption of interorganizational process innovations is due to the specific characteristics of this type of organizational process innovation. Unlike consumer product innovations, organizational process innovations in general, and interorganizational process innovation in particular, do not simply involve buying and installing equipment; they often require significant changes to the current organizational processes and practices (Swanson, 1994; Zmud and Apple 1992). Incorporating innovations into the organizational routines and processes takes time and considerable financial resources and is often more expensive than the original installation of the technological equipment (Bouchard 1993). Precisely because the incorporation of organizational innovations requires significant financial investments, the perceived costs of organizational innovation are likely to be major factors in shaping the adoption decision.

Table 2 summarises the studies included in this review that have discussed innovation costs. In total, thirty sources describing innovation adoption costs in supply networks have been found to contain relevant material. The final column of Table 2 identifies the type of costs identified in each article.

\section{Insert Table 2 about here}

\section{A framework of innovation costs and innovation stages}

Organizational innovation is often viewed as a three-stage innovation process: generation, acceptance and implementation (Thompson 1965; Pierce and Delbecq 1977). The three-stage model differentiates between the generation of an innovative idea or proposal, the acceptance of an innovation as represented by an organizational mandate for change, and the implementation of the innovation such that it becomes 
ingrained within the organizational behaviour. Subsequent innovation research has expanded on this original three-stage model, and while other stages have been identified they can readily be mapped onto Thompson's original three stages (Damanpour and Schneider 2006) (see Table 3). Moreover, the three-stage model of organizational innovation proposed by Thompson (1965) is widely considered in the innovation literature to be the most representative and conceptually straightforward of the innovation models (Damanpour and Schneider 2006; Kwon and Zmud 1987; Pierce and Delbecq 1977; Swanson 1994; Zmud 1982). For these reasons we have chosen Thompson's (1965) model as the underpinning stage model in this analysis.

\section{Insert Table 3 about here}

Based on a synthesis of the literature that considers the innovation, adoption and use of information systems to support interorganizational processes in supply networks it is possible to identify how different categories of cost map onto the different stages of organizational innovation (see Figure 1). The different categories of costs are summarized in Table 4. The table identifies six broad categories of innovation costs which can be applied to organizations seeking to implement interorganizational process innovations: development and initiation costs during the generation stage; switching costs and cost of capital during the acceptance stage; and implementation costs and relational costs during the implementation stage.

\section{Insert Figure 1 about here}

\section{Insert Table 4 about here}




\section{Generation Stage}

The process of innovation adoption starts with the generation of an idea or proposal that, when adopted and implemented, will result in some change within the adopting organization (Thompson 1965). One of the difficulties in comparing research in innovation is that writers use the same language to mean different things. This can be seen, for example, in the writing of Damanpour and co-authors, who use the term 'generation' to refer specifically to the in-house development of innovations and 'adoption' to describe the acquisition of an innovation developed by an external body (Damanpour and Wischnevsky 2006; Gopalakrishnan and Damanpour 1997). This clear distinction between different early stages of innovation is helpful in our analysis, where it is useful to be able to distinguish between those organizations that innovate through research and development activities and those that import ideas and technologies from other sources. In order to avoid confusion we will use the term 'developer' to refer to those organizations that develop innovations in-house and 'acquirer' to discuss those that acquire technology externally and whose core innovation is the processes and ways of working that surround the acquired technology. Translated into Thompson's three-stage model, this means that the generation stage involves either (i) the development of an innovation by developer organizations, through a set of activities by which a new process is developed; or (ii) the acquisition of an innovation by acquirer organizations, employing a set of activities through which the acquirers become aware of the potential of an innovation developed outside the organization and take steps to bring the innovation into the organization. Organizations can therefore incur two types of costs during the generation stage: development costs for developers, and awareness building costs 
(which we here term 'initiation costs') for acquirers.

\section{Development costs}

Internal development generally results from, and further enhances, core competencies, and allows developers to appropriate more of the profits from that innovation (Gopalakrishnan and Bierly 2001). In the context of pharmaceutical process innovation, Pisano (1997) defines the process innovation development cost as "the total number of hours spent by scientists and engineers developing the process, ... from the initiation of process research to the successful validation of the process at commercial scale" (p. 147). The same definition can be applied to interorganizational processes. Internal innovation development can be the result of in-house research and development activities of a sponsoring firm or may emerge through collaboration with other organizations (Tidd et al. 2005). Such collaborations, in the form of research consortia, strategic alliances or joint ventures, generally supplement rather than replace internal innovation activities (Faems et al. 2005; Tidd et al. 2005). The development of an interorganizational innovation can therefore involve two types of costs: internal development costs when an innovation is developed in-house, and external development costs when an innovation is developed through collaboration with other organizations.

Examples of internally developed interorganizational information systems innovations include the SABRE reservations system developed by American Airlines in the 1970s (Grossman 2004), the early ATM network systems developed independently by individual banks in the 1960s (Clemons et al. 1993; Zhu et al. 2006), and proprietary EDI and Internet based e-commerce systems such as WalMart's Retail Link in the 1980s and 1990s (Grossman 2004). Although these innovations were employed across 
multiple organizations, development activity was contained within single organizations and resulted from proprietary technologies developed by a sponsoring organization, which were then made available only to its partners (Zhu et al. 2006). Only the developing organization incurred the costs and reaped the benefits of the innovation.

However, few organizations have the financial wherewithal to develop such interorganizational process innovations single-handedly (Sparks and Wagner 2003; Wang 2006). Many interorganizational process innovations have been developed collaboratively by a range of organizations. The development costs associated with collaborative development (what Antonelli (1994) calls "elaboration costs") include the resources that are necessary to participate in standard setting consortia (Antonelli 1994), or other similar settings established to develop process innovations. Examples of interorganizational process innovations developed collaboratively by multiple organizations include industry wide e-commerce exchange platforms such as Covisint in the automotive industry (Gerst and Bunduchi 2005b), the Global NetXchange platform in the retail industry (Sparks and Wagner 2003) and industry wide technology standards such as the EPC standards for RFID technologies in the retail industry (Gerst and Bunduchi 2005a), and the OASIS standards for web service technologies in the IT industry (Graham et al. 2003). In contrast to the internally developed systems alluded to earlier, this second set of collaborative innovations were owned by multiple organizations who all shared the development costs and reaped the benefits accruing from their use.

Developing innovations in collaborative settings is costly in terms of both the time and the human resources required to participate in these settings (Foray 1994). For 
example, participation in industry wide standard consortium involves the payment of a membership fee (Gupta et al. 2008). In addition, often the participants have vested interests in incompatible outcomes from the innovation process, which can lead to further expense. For example standardization committees generally operate through consensus, which means that lengthy negotiations may be necessary, resulting in high costs to obtain a mutually agreed standard or technology (Farrell and Saloner 1988).

\section{Initiation costs}

Acquisition of an innovation from an external source saves the organization the cost of development, and potentially speeds up implementation (Gopalakrishnan and Bierly 2001). The costs to the acquirer at the generation stage result from activities focussed on gaining awareness of an innovation rather than on being involved in the technical development activities. Innovation acquirers must recognize the need for innovation, become aware of the process technologies that will fill that need, learn about the innovation and its suitability for their organization and then consider the full implications of adoption (Damanpour and Wishnevsky 2006; Meyer and Goes 1988). A number of mechanisms exist for learning about innovations, notably directly through deliberate scouting or indirectly through the professional and social networks in which organizational members are embedded (Tidd et al. 2005). Learning often leads to members of the acquiring organization considering the organizational fit of an innovation. These activities may eventually lead to a formal financial evaluation by the organization and to the decision to adopt an innovation, at which point the innovation progresses to Thompson's acceptance stage (Damanpour and Wishnevsky 2006; Meyer and Goes 1988). Building awareness and learning about a particular innovation require time and effort, adding to the total cost of the innovation adoption 
process.

Although the acts of searching for and acquiring innovations are acknowledged in the literature, the costs associated with these activities are not - though common sense tells us that they are not costless activities - and there is no currently widely accepted term for such costs. We have called them 'initiation costs' to reflect the fact that they result from the decision of an organization to initiate a search for a suitable technology to support innovation.

\section{Acceptance Stage}

The generation of an innovation may be followed by the second stage of Thompson's (1965) model, its acceptance by the adopting organization. During the acceptance stage an appropriate mandate and resources are provided to support the required changes (Thompson 1965). The mandate results from rational and political negotiations to persuade an organization to back the adoption of a process innovation (Cooper and Zmud 1990). Activities include evaluation of the new process from the technical, financial and strategic perspectives, developing a proposal for the acquisition of equipment, making the decision to accept the proposal and allocating resources for its acquisition, alteration and assimilation (Meyer and Goes 1988). These activities lead to potential switching costs and to the need to consider the costs of capital required for investment.

\section{Switching costs}

For many organizations the decision to adopt an interorganizational process innovation involves switching from an old technology and/or process to a new way of working, often requiring significant costs. In one of the few studies examining 
different types of costs associated with interorganizational systems innovation, Zhu et al. (2006) identify switching costs as a distinct category of costs, separate from the adoption costs associated with the migration to open standards interorganizational information systems innovation. They suggest that switching costs can make users of an existing interorganizational system more sensitive to the costs associated with the adoption of a new innovation (Zhu et al. 2006). The economics literature, for example, has identified switching costs as one of the principal barriers to the adoption of technological innovations in general (Farrell and Saloner 1985; Tang and Zannetos 1992). Switching costs have also been found to bind transacting organizations to one another and to a particular interorganizational system innovation (Swanson 1994). Compatibility between existing and new systems that reduces switching costs plays a significant role in explaining organizational innovation (Rogers 1995; Swanson 1994). For example, Forman (2005) found that organizations with prior investments in information technology, and who were therefore more likely to have Internet compatible technologies, were more likely to adopt Internet applications to support their business processes. In contrast, Zhu et al. (2006) found that existing investments in EDI acted as a deterrent to the adoption of open standards interorganizational information systems because the two types of systems were deemed incompatible. Consequently, the higher the switching costs, the less likely a firm is to abandon its current technology and adopt an interorganizational process innovation (Tang and Zannetos 1992).

Generally, switching costs result from a consumer's or organization's desire for compatibility between a current product or technology purchase and previous investments (Farrell and Shapiro 1988; Klemperer 1995). Most of the research on 
switching costs associated with organizational innovation has been described in the economics of standards literature (Antonelli 1995; David and Steinmueller 1994; Farrell and Saloner 1985; Shapiro and Varian 1999; Tang and Zannetos 1992) and draws on the model of switching costs in consumer markets (Farrell and Shapiro 1988) developed by Klemperer (1987; 1995). In both the economics and consumer markets literatures, the term 'switching costs' is used to include many different types of costs associated with using a new product, whether or not the new product replaces existing goods or services. In this analysis we follow the approach of Zhu et al. (2006), who considered organizations to have switching costs only if a new interorganizational information system replaces an existing (old) system. Switching costs therefore refer to the compatibility costs associated with existing investments in complementary resources that work only with a particular process or technology. These resources can no longer be employed once a user switches to another process or technology (Farrell and Saloner 1988; Klemperer 1987; 1995). In the case of information technology innovations (which include interorganizational systems innovations), Powell and Dent-Micallef (1997) differentiate between technological and organizational complementary resources. It is therefore possible to differentiate between organizational compatibility costs associated with organizational complementary resources and technological compatibility costs associated with technological complementary resources. Complementary technology resources include, for example, existing hardware and software (Forman 2005). Complementary organizational resources include a wide range of factors including capabilities in marketing, distribution or service capabilities (Sahay and Riley 2003). The costs associated with such non-technological complementary resources are especially relevant in the case of information technology system innovations. Previous 
research has shown that complementary organizational investments may be much larger than the original investment in the system as a consequence of the organizational adjustments required to accommodate the technology (Bessen 2002; Brynjolfsson and Hitt 2000).

\section{Cost of capital (uncertainty of investment cost)}

During the acceptance stage of an innovation, an organization provides the resources necessary for implementation within the host organization (Thompson 1965). These resources can be in the form of debt, equity or investment from retained earnings. The decision to invest in an innovation can be thought of in the same way as any other investment decision: the cost of capital will depend on the degree of risk associated with a particular investment, and the degree of risk will depend on the level of uncertainty associated with innovation investment. In the manufacturing context, a high cost of capital has been found to be one of the factors explaining the lack of adoption of advanced technological innovations (Baldwin and Lin 2002).

There are two types of uncertainty associated with information technology investments such as interorganizational system innovations: technological uncertainty and market uncertainty (Mata et al. 1995). Technological uncertainty reflects the risk that an information technology investment may not meet its performance targets on time and at the projected cost (Mata et al. 1995). Technological risks associated with poor network reliability and data security have been found to hamper the adoption of Internet based interorganizational systems (Soliman and Janz 2004).

Market uncertainty considers the risks associated with negative reactions from potential stakeholders, including customers, competitors, suppliers, the general public, 
the media, or government (Markus 2000). For example, the adoption of emerging interorganizational process innovations with as yet unproven benefits, such as RFID as a track-and-trace technology for supply network management, will be regarded as being a significantly higher risk investment (Gerst and Bunduchi 2005a), meriting higher interest rates, than the adoption of a proven interorganizational process technology like a new generation of barcode systems where there is much less uncertainty involved in the cost/benefit calculations.

\section{Implementation Stage}

The final stage in the organizational innovation adoption process is implementation, which results in an innovation being adopted into a sustained and recognisable behaviour pattern within the organization (Thompson 1965). The implementation of process innovations involves the acquisition of a process technology, its installation, and any necessary development work. At this stage organizational procedures are adapted to deal with the new application, and organizational members are trained both in the procedures and in how to use the new process technology (termed 'adaptation' by Cooper and Zmud 1990). Organizational members are persuaded to commit to the new process and ways of working (acceptance) and use of the process technology is encouraged as part of the normal activities of the organization (routinization). At the end of this stage the new process technologies should be widely used and integrated with other systems to give greater organizational effectiveness (infusion) (Cooper and Zmud 1990). Implementation therefore consists of a series of adaptive actions that involve modifying the innovation to fit the needs of the organization, changing the way in which the organization works, persuading users to accept the new technology, and then ensuring the penetration of the innovation throughout the organization 
until it becomes a routine feature of the organization's activities (Damanpour and Schneider 2006; Meyer and Goes 1988)

\section{Implementation (investment) costs}

The costs associated with the implementation of interorganizational process innovations, in particular interorganizational information technology systems, have been shown in the literature to play a significant role in shaping the innovation process. Implementation costs can be classified into direct and indirect costs (Hochstrasser 1992). Direct costs are readily attributable to the implementation and operation of technologies, and include the costs associated with the initial user specification of the system, unanticipated hardware and software costs and other costs including those related to security, system development costs, and maintenance costs (Irani et al. 1997; Irani and Love 2000/2001). Indirect costs have a strong social element (Hochstrasser 1992) and are often regarded as 'hidden' costs, which are much more difficult to identify and even more difficult to quantify (Fitzgerald 1998; Irani et al. 1997; Irani and Love 2000/2001). Indirect costs include organizational and human costs (Irani et al. 1997; Irani and Love 2000/2001; Ryan and Harrison 2000). Human costs can be attributed to individuals, for example on-the-job employee training and management time. Organizational costs arise largely because effective implementation and assimilation of new technologies requires their integration into existing or redefined organizational work routines, a process which often involves changes to current technologies, practices, structures and work processes (Chatterjee et al. 2002; Damanpour and Schenider 2006; Gallivan 2001). These changes initially lead to reductions in productivity until the users become familiar with the technology and new ways of working. 
Initial investment costs associated with training and integrating an interorganizational information system with existing organizational systems (Premkumar et al. 1994), learning to use the new system (Chau and Tam 1997), and the financial and nonfinancial costs associated with implementing new systems (Zhu et al. 2006) have all been found to have a negative influence on adoption of interorganizational innovations. Findings from studies of other types of technological innovations have also found that implementation costs influence the adoption decision. For example, a large survey of the adoption of advanced technologies in the manufacturing sector in Canada found that the failure of organizations to adopt the technologies could be attributed to the direct costs of acquiring, installing and maintaining the equipment, and to indirect costs resulting from the difficulties associated with implementing organizational change to accommodate the innovation (Baldwin and Lin 2002). Similarly, in studying the characteristics of information technology chargeback systems, Ross et al. (1999) suggest that charging implementation costs to individual user business units may deter the adoption of new information technologies.

\section{Relational costs - costs associated with the lack of trust}

Adoption of an interorganizational process innovation requires the implementation of systems that span organizational boundaries, meaning that any analysis of costs and benefits must incorporate the impact on more than one organization (Johnston and Vitale 1988). The pattern of innovation use may vary depending on the nature of relationships among innovation adopters within a supply network. One of the key relational characteristics that has been analysed in the context of interorganizational process innovation is trust (Bunduchi 2007; Hart and Saunders 1998; Kumar and van Dissel 1996; Meier 1995). The way organizations use interorganizational process 
innovations, such as electronic markets, varies significantly depending on the presence or absence of trust (Bunduchi 2005). For example, the absence of trust leads to the adoption of innovations such as electronic auctions, while the presence of trust stimulates investments in technologies such as discussion fora and tools for collaborative inventory planning (Markus and Christiaanse 2003).

Lack of trust within a supply network involved in the adoption of inter-organisational process innovations leads to additional innovation costs. Research on innovation in supply networks has shown that the absence of trust can lead to ill-feeling and resentment within user communities, to tensions and conflicts, and ultimately to the withdrawal of some of users from the system (Allen et al. 2000; Gerst and Bunduchi 2005b), increasing the costs associated with innovation adoption. In contrast, the presence of trust between supply network actors (Hart and Saunders 1998) and the provision of price incentives to support trust (Nakayama 2000) have both been found to positively influence the likelihood of the adoption of process innovations, such as EDI, in supply networks. Similar results have been reported for the adoption of Internet-based interorganizational innovations for use where trust exists between organizations (Soliman and Janz 2004). Consequently, the costs of implementing interorganizational process innovations will vary depending on the existence of trust between adopting organizations.

\section{Implications for research and practice}

To date there have been few attempts in the literature to identify the different components of innovation costs. This paper has synthesised existing literature that discusses innovation costs, particularly in the context of interorganizational process 
innovation, and has developed a single, coherent framework that categorizes the costs that organizations incur during the different stages of the organizational innovation process. For researchers, the framework provides an integrated view of the different costs associated with organizational innovation, and as such it serves as the impetus for further research into the role that costs play in shaping the adoption and use of interorganizational process innovations.

The framework can also serve as a tool to alert policy makers to the types of costs incurred by those adopting interorganizational innovations. For example, the framework distinguishes between development costs associated with innovation through internal development or collaboration with others and initiation costs associated with acquiring an externally developed innovation. This suggests that different types of financial incentives are appropriate depending on whether policies aim to support the development of radically new technologies or the diffusion of existing innovations. Again, the existence of a comprehensive framework of costs can help to promote more appropriate policy decisions about the deployment of resources.

For practitioners, research indicates that a clear strategic investment rationale, in the form of a strong value proposition, provides a powerful tool for managers to help them make sense of an innovation (Chatterjee et. al. 2002). A strong rationale for investment ultimately increases the likelihood that the innovation will be successfully assimilated. The framework described here provides a structured means by which managers can identify potential costs of adoption. Having this information can help in developing stronger business cases for investment. For example, Ross et al. (1999) found that an understanding of the different costs associated with information technology usage is essential to support a robust assessment by business units of 
the value added by information technology services. However, more often than not such an understanding is lacking at the business unit level, leading to underperformance. A comprehensive framework should enable decision makers to take into account the full range of costs when considering the adoption of a new system, rather than focusing simply on the hardware and software costs.

Our study also reinforces the importance of considering intangible costs in the context of innovation investments. The framework identifies costs that may not routinely be considered in investment decisions. Despite attempts to improve the way in which investments with strong elements of intangibility are assessed, many organizations still lean towards simple accounting measures such as payback, net present value and internal rate of return that assess only readily quantifiable financial factors. The additional costs proposed here, while difficult to quantify, should also provoke further discussion among researchers, managers and policy makers with an interest in the adoption of interorganizational process innovations.

\section{Future research}

This paper has put forward potential areas of future research that will assist us in understanding more fully the role of costs in shaping organizational innovations. We have identified different categories of costs associated with organizational innovation. Research is now needed to quantify the magnitude to these costs for particular process innovations, such as e-business exchange platforms or RFID technologies in supply networks. Future studies could examine the costs incurred by both developer and acquiring organizations within a particular industry. As has been acknowledged, some costs are easier to assess than others (direct costs, for example, are generally easier to 
identify and attach a number to than are indirect costs which, for example, rely on an estimation of the impact of low staff moral resulting from working with an unfamiliar redesigned process). Eliciting the views of organizational decision makers about the impact of these costs and their role in shaping their adoption decisions could provide a starting point in developing this study. A mixed methods approach, employing techniques such as the Analytical Hierarchy Process (Saaty 1980) to assist in structuring the answers of respondents, may provide the way forward for early exploratory studies.

The magnitude of the different innovation costs is likely to vary depending on the timing of adoption. For example, existing studies in innovation management have shown that early adopters influence the shaping of innovations to meet their own needs and requirements (von Hippel 1988). Consequently, their switching costs are likely to be lower than those of late adopters or laggards who did not influence the design of the innovation. Similarly, studies of technology change have shown that in the later stages of innovation evolution the direct costs associated with the implementation of an innovation are likely to decrease due to the combined effects of economies of scale and the learning curve (Anderson and Tushman 1990; Utterback and Abernathy 1975). Such cost reductions are likely to benefit late adopters who will adopt a technology only once it is proven in the market (Rogers 1995). Research is needed to identify the magnitude of the different categories of costs associated with organizational innovation depending on the timing of adoption. This research would involve a longitudinal study of the adoption of a particular type of innovation through a population of organizations over time. 
Other possible extensions of this study would include examining the role of costs in shaping organizational innovation in other contexts. Following the advice of Zmud (1982) we have considered only the context of interorganizational supply network innovation. Further work is needed to assess whether the cost categories identified here might be applicable to other types of innovations. In doing so it would be necessary to consider whether other categories of costs emerge as relevant in other contexts. For example the possible need for data protection in the use of RFID has led to the suggestion that costs associated with privacy issues may be incurred by innovations such as RFID when tags have the potential to reach end customers (see for example Peslak 2005). Such research would refine the typology of costs associated with the adoption of innovation to enable a wider generalisation. Finally, there is a need to develop a similar comprehensive framework to consider the benefits accruing from interorganizational innovations in supply networks. Such an analysis would complement this study and help us to understand more fully the factors shaping innovation adoption in supply network and other contexts.

\section{Conclusion}

Our review of interorganizational process innovation costs has shown that whilst there is evidence that costs significantly influence the pattern of organizational innovation, researchers have made only limited attempts to clarify the precise nature of these costs. Most studies include only one category of innovation costs in their analysis or treat innovation cost as a single variable. Based on a synthesis of the innovation literature this paper has developed a framework of costs for interorganizational process innovations. The costs map onto the different stages in the innovation lifecycle outlined by Thompson (1965). The framework identifies six broad 
categories of innovation adoption costs: development costs and initiation costs associated with the generation of an innovation, switching costs and costs of capital associated with the acceptance of an innovation, and implementation costs and relational costs associated with the implementation of an innovation within the organization.

We have presented a set of arguments that serve to counterbalance the common assumption in the existing innovation literature, that costs are easily measured, and are simply the financial costs of equipment acquisition. We also note that it is important to recognise that innovation costs often include significant intangible costs, which can be measured only with difficulty.

In conclusion, the framework developed in this paper contributes to the understanding of how and where costs accrue when organizations generate, adopt and implement interorganizational process innovations. The framework serves not only to organize existing literature and but also to provide the impetus for future research. 


\section{References}

Allen, D., Colligan, D., Finnie, A. and Kern, T. (2000). Trust, power and interorganizational information systems: the case of the electronic trading system TransLease. Information Systems Journal, 10, 21 - 40.

Anderson, P. and Tushman, M. L. (1990). Technological discontinuities and Dominant Designs: A Cyclical Model of Technological Change. Administrative Science Quarterly, 35, 604-633.

Antonelli, C. (1994). Localized technological change and the evolution of standards as economic institutions. Information Economics and Policy, 6, 195 - 216.

Antonelli, C. (1995). The Economics of Localized Technological Change and Industrial Dynamics. Dordrecht: Kluwer Academic Publishers.

Attewell, P. (1992). Technology diffusion and organizational learning: The case of business computing. Organization Science, 3, 1-19.

Baldwin, J. and Lin, Z. (2002). Impediments to advanced technology adoption for Canadian manufacturers. Research Policy, 31, 1-18.

Bessen, J. (2002). Technology adoption costs and productivity growth: the transition to information technology. Review of Economic Dynamics, 5, 443 - 469.

Bouchard, L. (1993). Decision criteria in the adoption of EDI Proceedings of the $13^{\text {th }}$ International Conference on Information Systems, Orlando, Florida, December 1993, 
pg. 365-376.

Brynjolfsson, E. and Hitt, L. M. (2000). Beyond computation: Information technology, organizational transformation and business performance. The Journal of Economic Perspectives, 14, 23 - 48.

Bunduchi R. (2005). Business relationships in Internet based electronic markets: the role of goodwill trust and transaction costs. Information Systems Journal, 15, 321341.

Bunduchi R. (2007). An empirical investigation of the role of trust and power in shaping the use of electronic markets. In Li F. (ed.), Social implications and challenges of e-business. Hershey: Information Science Reference.

Chatterjee, D., Grewal, R. and Sambamurthy, V. (2002). Shaping up for ECommerce: Institutional Enables of the Organizational Assimilation of Web Technologies. MIS Quarterly, 26, 65-89.

Chau, P.Y.K. and Tam, K.Y. (1997) Factors affecting the adoption of open systems: An exploratory study MIS Quarterly, 21, 1 - 24.

Chwelos, P., Bensabat, I. and Dexter, A.S. (2001). Research report: Empirical test of an EDI adoption model. Information Systems Research, 12, 304-321.

Clemons, E.K. (1991). Evaluation of Strategic Investments in Information Technology. Association for Computing Machinery. Communications of the ACM, 34, $24-36$.

Clemons, E.K., Reddi, S.P. and Row, M.C. (1993). The impact of information 
technology on the organization of economic activity: The "move to the middle" hypothesis. Journal of Management Information Systems, 10, 9-35.

Cooper, R.B. and Zmud, R.W. (1990). Information technology implementation research: A technological diffusion approach. Management Science, 36, 123-139.

Cunningham, C. and Tynan, C. (1993). Electronic trading, inter-organizational systems and the nature of buyer-seller relationships: the need for a network perspective. International Journal of Information Management, 13, 3-28.

Damanpour, F. and Schneider, M. (2006). Phases of the adoption of innovation in organizations: effects of environment, organization and top managers British Journal of Management, 17, 215-236.

Damanpour, F. and Wischnevsky, J.D. (2006). Research on innovation in organizations: Distinguishing innovation-generating from innovation-adopting organizations. Journal of Engineering Technology Management, 23, 269-291.

David, P.A. and Steinmueller, W.E. (1994). Economics of compatibility standards and competition in telecommunication networks. Information Economics and Policy, 6, 217-241.

Edwards, T., Battisti, G. and Neely, A. (2004). Value creation and the UK economy: a review of strategic options. International Journal of Management Reviews 5 - 6, 191 $-213$.

Faems, D., Looy, B. V. and Debackere, K. (2005). Interorganizational Collaboration and Innovation: Toward a Portfolio Approach. The Journal of Product Innovation 
Management, 22, 238 - 250.

Farrell, J. and Saloner, G. (1985). Standardization, Compatibility, and Innovation. The Rand Journal of Economics, 16, 70 - 83.

Farrell, J. and Saloner, G. (1988). Coordination Through Committees and Markets. The Rand Journal of Economics, 19, 235 - 252.

Farrell, J. and Shapiro, C. (1988). Dynamic Competition with Switching Costs. The Rand Journal of Economics, 19, 123 - 137.

Fitzgerald, G. (1998). Evaluating information systems projects: a multidimensional approach. Journal of Information Technology, 13, 15 - 27.

Foray, D. (1994). Users, standards and the economics of coalitions and committees. Information Economics and Policy, 6, 269 - 293.

Forman, C. (2005). The Corporate Digital Divide: Determinants of Internet Adoption. Management Science, 51, 641-654.

Gallivan, M.J. (2001). Organizational adoption and assimilation of complex technological innovations: Development and application of a new framework. The DATA BASE for Advances in Information Systems, 32, 51-85.

Gerst M. and Bunduchi R. (2005a). Challenges in the adoption of RFID standards. In Santucci G. \& Frederix F. (eds.), Strengthening Competitiveness through Production Networks. Luxembourg: European Communities.

Gerst M. and Bunduchi R. (2005b). Shaping IT standardisation in the automotive 
industry - the role of power in driving portal standardisation. Electronic Markets, 15, $335-343$.

Gopalakrishnan, S. and Bierly, P. (2001). Analyzing innovation adoption using a knowledge-based approach. Journal of Engineering Technology Management, 18, $107-130$

Gopalakrishnan, S. and Damanpour, F. (1995). A review of innovation research in economics, sociology and technology management. Omega, International Journal of Management Science, 25, 15-28.

Grossman, M. (2004). The role of trust and collaboration in the Internet-enabled supply chain. The Journal of American Academy of Business, 5, 391-396.

Graham, I., Pollock, N., Smart. A. and Williams, R. (2003). Institutionalisation of ebusiness standards. Standard Making: A critical Research Frontier for Information Systems. MISQ Special Issue Workshop, Seattle, December 12-14.

Gupta, A., Kauffman, R.J. and Wu, A.P. (2008). Do Firm R\&D Investments Drive Decisions to Join? On the Value of Standard-Setting Organizations in the Consumer Electronics Industry, $41^{\text {st }}$ HICSS Conference, Hawaii, January 7-10.

Harland, C., Lamming, R., Zheng, J. and Johnsen, T. (2001). A taxonomy of supply networks. Journal of Supply Chain Management 37, 21-27.

Hart, P. J. and Saunders, C. S. (1998). Emerging Electronic Partnerships: Antecedents and Dimensions of EDI Use from the Supplier's Perspective. Journal of Management Information Systems, 14, 87 - 111.

Hochstrasser, B. (1992). Justifying IT Investments. Proceedings of Advanced 
Information Systems Conference: The new technologies in today's business environment, June, London, pp. 17-28.

Iacovou, C.L., Benbasat, I. and Dexter, A.S. (1995). Electronic data interchange and small organizations: adoption and impact of technology. MIS Quarterly, 19, 465-485.

Irani, Z., Ezingeard, J.-N. and Grieve, R. J. (1997). Integrating the costs of a manufacturing IT/IS infrastructure into the investment decision-making process. Technovation, 17, 695-706.

Irani, Z. and Love, P. E. D. (2000/2001). The propagation of technology management taxonomies for evaluating investments in information systems. Journal of Management Information Systems, 17, 161 - 177.

Jimenez-Martinez, J. and Polo-Redondo, Y. (2004). The influence of EDI adoption over its perceived benefits. Technovation, 24, 73-79.

Johnston, H. R. and Vitale, M. R. (1988). Creating Competitive Advantage with Interorganizational Information Systems. MIS Quarterly, 12, 153-165.

Klemperer, P. (1987). Markets with Consumer Switching Costs. The Quarterly Journal of Economics, 102, 375 - 394.

Klemperer, P. (1995). Competition when consumers have switching costs: An overview with applications to industrial organization, macroeconomics, and international trade. The Review of Economic Studies, 62, 515 - 539.

Kumar, K. and van Dissel, H.G. (1996). Sustainable collaboration: managing conflict and cooperation in interorganizational systems. MIS Quarterly, 20, 279-300. 
Kwon, T.H. and Zmud, R.W. (1987). Unifying the fragmented models of information systems implementation. In Borland, R.J. and Hirschheim, R.A. (eds.) Critical issues in Information Systems research, Chichester: John Wiley \& Sons.

Mansfield, E. (1993). The diffusion of flexible manufacturing systems in Japan, Europe and the United States. Management Science, 39, 149-159.

Markus, M. L. (2000). Toward an integrated theory of IT-related risk control. In Baskerville, R., Stage, J. and DeGross, J. I. (eds.) Organizational and social perspectives on information technology, Boston: Kluwer Academic Publishers.

Markus, M. L. and Christiaanse, E. (2003). Adoption and impact of collaboration electronic marketplaces. Information systems and e-Business management, 1, 139155.

Mata, F. J., Fuerst, W. L. and Barney, J. B. (1995). Information technology and sustained competitive advantage: A resource-based analysis. MIS Quarterly, 19, 487 505.

McFarlan, F. W. (1981). Portfolio approach to information systems. Harvard Business Review, 59, 142-151.

Meier, J. (1995). The importance of relationship management in establishing successful interorganizational systems. Journal of Strategic Information Systems, 4, $135-149$.

Meyer, A.D. and Goes, J.B. (1988). Organizational assimilation of innovations: A multilevel contextual analysis. The Academy of Management Journal, 31, 897-923. 
Mukhopadhyay, T. and Kekre, S. (2002). Strategic and operational benefits of electronic integration in B2B procurement processes. Management Science, 28, 13011313.

Mukhopadhyay, T., Kekre, S. and Kalathur, S. (1995). Business value of information technology: A study of electronic data interchange. MIS Quarterly, 19, 137-156.

Nakayama, M. (2000). E-commerce and firm bargaining power shift in grocery marketing channels: A case of wholesalers' structured document exchanges. Journal of Information Technology, 15, 195 - 210.

Peslak, A. (2005). An ethical exploration of privacy and radio frequency identification. Journal of Business Ethics, 59, 327-345.

Pierce, J. L. and Delbecq, A. L. (1977). Organization Structure, Individual Attitudes and Innovation. The Academy of Management Review, 2, 27 - 37.

Pisano, G.P. (1997). The Development Factory: Unlocking the Potential of Process Innovation. Boston: Harvard Business School Press.

Powell, T. C. and Dent-Micallef, A. (1997). Information technology as competitive advantage: The role of human, business, and technology resources. Strategic Management Journal, 18, 375 - 405.

Premkumar, G., Ramamurthy, K. and Nilakanta, S. (1994). Implementation of Electronic Data Interchange: An innovation diffusion perspective. Journal of Management Information Systems, 11, 157-186.

Rogers E.M. (1995). Diffusion of Innovation, New York: Free Press. 
Ross, J.W., Vitale, M.R. and Mathis Beath, C. (1999). The untapped potential of IT chargeback. MIS Quarterly, 23, 215-237.

Ryan, S. D. and Harrison, D. A. (2000). Considering social subsystem costs and benefits in information technology investment decisions: A view from the field on anticipated payoffs. Journal of Management Information Systems, 16, 11 - 38.

Saaty T (1980). The Analytical Hierarchy Process. New York: McGraw Hill.

Sahay, A. and Riley, D. (2003). The role of resource access, market considerations, and the nature of innovation in pursuit of standards in the new product development process. The Journal of Product Innovation Management, 20, 338 - 355.

Shapiro, C. and Varian, H. R. (1999). The art of standard wars. California Management Review, 41, 8 - 32.

Smith, H. A., McKeen, J. D. and Staples, D. S. (2001). Risk management in information systems: problems and potential. Communications of the Association for Information Systems, 7, 1 - 28.

Soliman, K.S. and Janz, B.D. (2004). An exploratory study to identify the critical factors affecting the decision to establish Internet-based interorganizational information systems. Information \& Management, 41, 696-706.

Sparks, L. and Wagner, B.A. (2003). Retail exchanges: a research agenda. Supply Chain Management, 8, 201-208

Subramani, M. (2004). How do suppliers benefit from information technology use in supply chain relationships? MIS Quarterly, 28, 45-73. 
Sumner, M. (2000). Risk factors in enterprise-wide/ERP projects. Journal of Information Technology, 15, 317 - 327.

Swanson, E. B. (1994). Information systems innovation among organizations. Management Science, 40, 1069 - 1092.

Tang, M.-J. and Zannetos, Z. S. (1992). Competition Under Continuous Technological Change. Managerial and Decision Economics, 13, 135 - 148.

Thompson, V. (1965). Bureaucracy and Innovation. Administrative Science Quarterly, 10, 1 - 20.

Tidd, J., Bessant, J. and Pavitt, K. (2005). Managing Innovation: Integrating technological, market and organizational change, Chichester: John Wiley and Sons.

Tornatzky, L.G. and Klein, K.J. (1982). Innovation characteristics and innovation adoption - implementation: A meta-analysis of findings. IEEE Transactions on Engineering Management, 29, 28-45.

Tranfield, D., Denyer, D. and Smart, P. (2003). Towards a methodology for developing evidence-informed management knowledge by means of systematic review. British Journal of Management, 14, 207 - 222.

Utterback, J.M. (1971). The process of technological innovation within the firm. The Academy of Management Journal, 14, 75-88.

Utterback, J.M. and Abernathy, W.J. (1975). A Dynamic Model of Process and Product Innovation. Omega, International Journal of Management Science, 3, 639656. 
von Hippel, E. (1988). The Sources of Innovations. New York: Oxford University Press.

Wang, J. (2006). Economies of IT Systems at Wal-Mart - An Historical Perspective. Academy of Information and Management Sciences Journal, 9, 45-66.

Weber, M.M. and Kantamneni, S.P. (2002). POS and EDI in retailing: an examination of underlying benefits and barriers. Supply Chain Management, 7, 311-317.

Wilkinson, I. and Young, L. (2002). On cooperating firms, relations and networks. Journal of Business Research, 55, 123 - 132.

Zhu, K., Kraemer, K.L., Gurbaxani, V. and Xu, S. (2006). Migration to open-standard interorganizational systems: Network effects, switching costs, and path dependency. MIS Quarterly, 30, 515-539.

Zmud, R. W. (1982). Diffusion of Modern Software Practices: Influence of Centralization and Formalization. Management Science, 28, 1421 - 1431.

Zmud, R.W. and Apple, L. E. (1992). Measuring technology incorporation/infusion. Journal of Product Innovation Management, 9, 148-155. 


\section{Appendix}

Figure 1. The framework of process innovation costs and organizational innovation stages

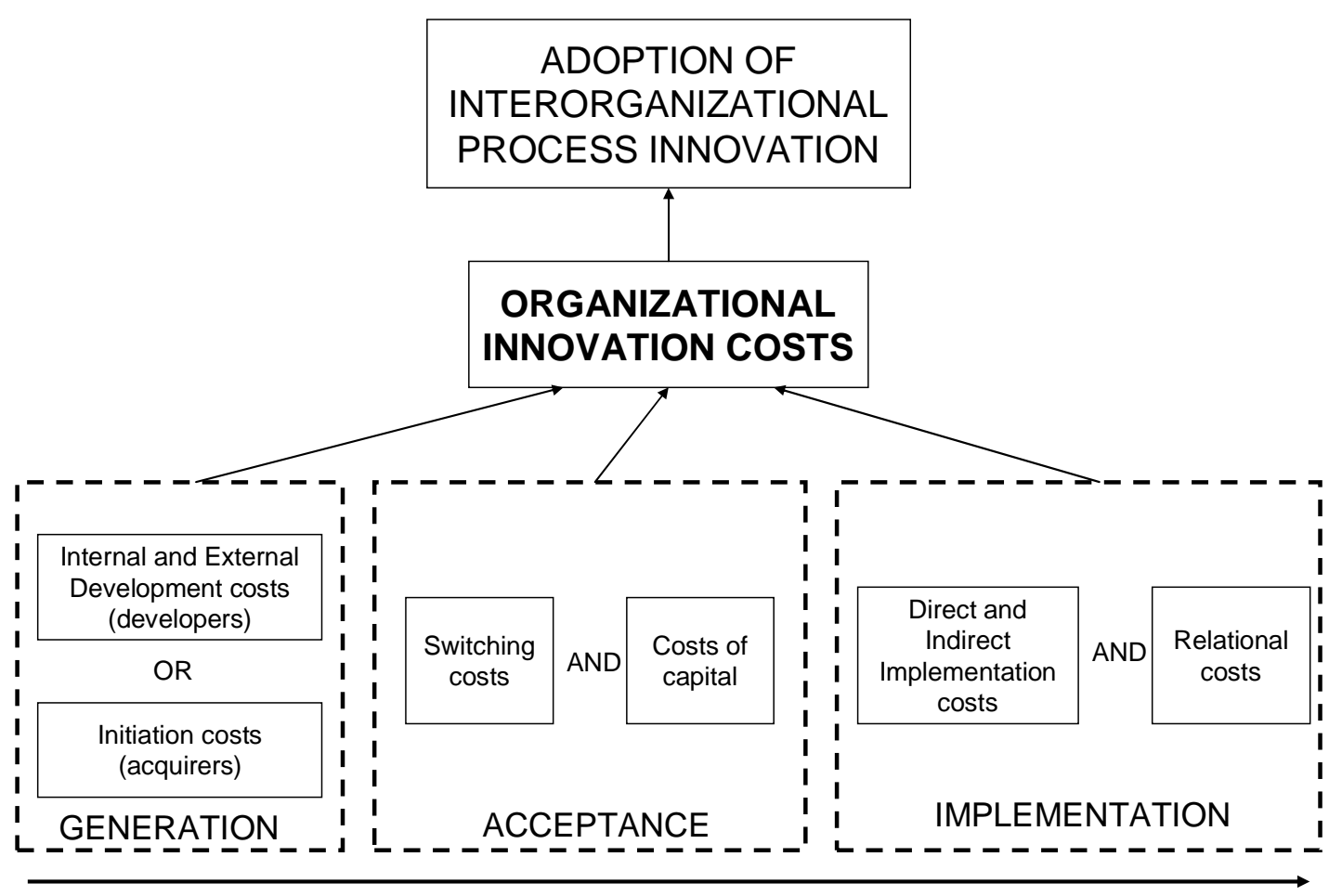

STAGES IN ORGANIZATIONAL INNOVATION PROCESS 
Table 1. Selected research on benefits associated with the adoption of interorganizational process innovations

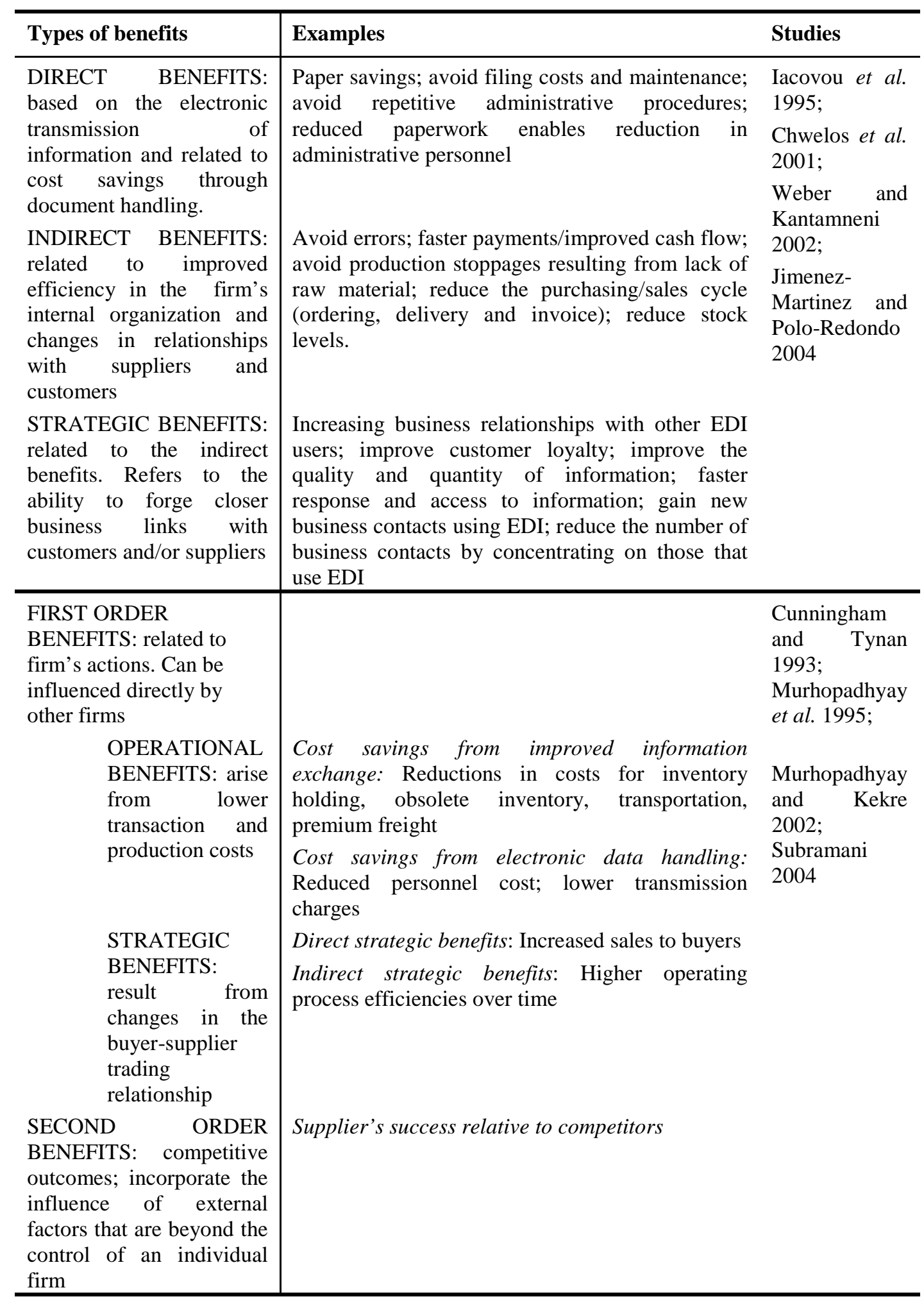


Table 2. A review of studies of innovation adoption costs in supply networks

\begin{tabular}{|c|c|c|c|}
\hline Reference & Main findings & Methodology & Type of cost \\
\hline $\begin{array}{l}\text { Allen et al. } \\
2000\end{array}$ & $\begin{array}{l}\text { Describes a study of an electronic trading community. Found that the system was failing as a consequence of } \\
\text { relational factors pertaining to lack of trust between users, a perceived unfair balance of power in determining rules of } \\
\text { trade and different expectations among stakeholders. }\end{array}$ & $\begin{array}{l}\text { Action } \\
\text { research }\end{array}$ & $\begin{array}{l}\text { Relational cost } \\
\text { (trust) }\end{array}$ \\
\hline $\begin{array}{l}\text { Antonelli } \\
1994\end{array}$ & $\begin{array}{l}\text { Discusses the development of technology standards and suggests that both supply and demand side influence } \\
\text { standards development in the long-term. It demonstrates that organizations can benefit from switching from their own } \\
\text { specification to a more widely adopted standard accepted in the market place. }\end{array}$ & Model & $\begin{array}{l}\text { Development } \\
\text { cost }\end{array}$ \\
\hline $\begin{array}{l}\text { Baldwin and } \\
\text { Lin } 2002\end{array}$ & $\begin{array}{l}\text { Examines the problems faced by manufacturers adopting 'advanced' technologies. Includes identification of } \\
\text { impediments to adoption that are classed as cost-related (including cost of hardware, software and maintenance), } \\
\text { institution-related, labor-related, organization-related and information-related. The last relate to factors such as } \\
\text { imperfect markets for knowledge pertaining to scientific and technical information. }\end{array}$ & Survey & $\begin{array}{l}\text { Cost of capital } \\
\text { Implementation } \\
\text { cost } \quad \text { (direct } \\
\text { costs) }\end{array}$ \\
\hline $\begin{array}{l}\text { Chau and } \\
\text { Tam } 1997\end{array}$ & $\begin{array}{l}\text { Develops an adoption model for open system innovations which includes seven determinants of adoption: market } \\
\text { uncertainty, complexity of IT infrastructure, satisfaction with existing systems, formalization of systems development } \\
\text { and management, perceived benefits, perceived barriers, and perceived importance of compliance with standards, } \\
\text { interoperability and interconnectivity. Costs are analyzed as part of perceived barriers - in particular high migration } \\
\text { costs, the need to learn new ways of working with unfamiliar systems, and the costs of decommissioning existing } \\
\text { systems - and found to hamper adoption. }\end{array}$ & Survey & $\begin{array}{l}\text { Implementation } \\
\text { costs (indirect } \\
\text { costs) }\end{array}$ \\
\hline $\begin{array}{l}\text { Clemons } \\
1991\end{array}$ & $\begin{array}{l}\text { Explores lessons from the implementation of information systems. Within the context of a case study identifies and } \\
\text { discusses different categories of risk, including financial, technology, project, functionality and systemic risks.. }\end{array}$ & Case study & Cost of capital \\
\hline $\begin{array}{l}\text { Farrell and } \\
\text { Saloner } 1985\end{array}$ & $\begin{array}{l}\text { Examines the costs associated with standardization. It argues that once firms are bound together by the benefits of } \\
\text { compatibility or standardization of a new technology, they will be extremely reluctant to move to a new and better } \\
\text { technology because of the coordination problems involved. }\end{array}$ & Model & Switching costs \\
\hline $\begin{array}{l}\text { Farrell and } \\
\text { Saloner } 1988\end{array}$ & $\begin{array}{l}\text { Explains and evaluate the choices that firms have in developing compatibility standards around a new technology. The } \\
\text { argument is that such compatibility can be achieved either (i) through unilateral action, with one player leading the } \\
\text { way and others required to follow (market mechanism); (ii) through consultation and negotiation, usually in } \\
\text { committees, before choices are made or (iii) by a combination of (i) and (ii). The study show that different } \\
\text { mechanisms are appropriate under different conditions, with the first mechanism less likely to be successful, unless }\end{array}$ & Model & $\begin{array}{l}\text { Development } \\
\text { cost } \\
\text { Switching costs }\end{array}$ \\
\hline
\end{tabular}




\begin{tabular}{|c|c|c|c|}
\hline & one player holds a powerful position in the market & & \\
\hline $\begin{array}{l}\text { Fitzgerald } \\
1998\end{array}$ & $\begin{array}{l}\text { Identifies limitations to traditional methods of IT investment appraisal and outlines a methodology for overcoming } \\
\text { these limitations. Suggests that many IT/IS investments that exceed the anticipated costs suffer from 'hidden' costs } \\
\text { that have not been factored into the investment decision, including costs that occur outside the IT department. Costs of } \\
\text { user involvement and user-management are among the hidden costs. }\end{array}$ & Theory & $\begin{array}{l}\text { Implementation } \\
\text { cost (indirect } \\
\text { costs) }\end{array}$ \\
\hline Foray 1994 & $\begin{array}{l}\text { Discusses the importance of user involvement in the development of IT standards and difficulties associated with } \\
\text { involving users in the standardization process. }\end{array}$ & $\begin{array}{l}\text { Analytical } \\
\text { model }\end{array}$ & $\begin{array}{l}\text { Development } \\
\text { cost }\end{array}$ \\
\hline Forman 2005 & $\begin{array}{l}\text { Examines the diffusion of Internet technologies and finds that prior IT investments and workplace organization } \\
\text { decisions affect the likelihood of adoption. For example, prior IT investments such as recent investment in client } \\
\text { server networking applications are found to slow down adoption by creating switching costs. }\end{array}$ & Model & Switching costs \\
\hline $\begin{array}{l}\text { Gupta } \text { et } a l \\
2008\end{array}$ & $\begin{array}{l}\text { Examines the factors affecting a firm's decision to join a standard setting consortium and considers the costs of } \\
\text { membership. The study finds that by joining a standard setting organization a firm reduces its research and } \\
\text { development costs. }\end{array}$ & $\begin{array}{l}\text { Statistical } \\
\text { model }\end{array}$ & $\begin{array}{l}\text { Development } \\
\text { costs }\end{array}$ \\
\hline $\begin{array}{l}\text { Hart and } \\
\text { Saunders } \\
1998\end{array}$ & $\begin{array}{l}\text { Finds that customer power was negatively related to the volume of EDI transactions and that trust was more important } \\
\text { than power in increasing the range of different EDI transactions. }\end{array}$ & Survey & $\begin{array}{l}\text { Relational cost } \\
\text { (trust) }\end{array}$ \\
\hline $\begin{array}{l}\text { Hochstrasser } \\
1992\end{array}$ & $\begin{array}{l}\text { Describes a framework for justifying investments in IT. Considers both the main systems objectives and what are } \\
\text { termed 'second order effects' related to human and organizational factors. The framework takes into account critical } \\
\text { success factor, risk assessment, business performance indicators and strategic alignment. Describes a way of } \\
\text { monitoring and evaluating investments over time. }\end{array}$ & Theory & $\begin{array}{l}\text { Implementation } \\
\text { cost (direct \& } \\
\text { indirect) }\end{array}$ \\
\hline $\begin{array}{l}\text { Irani et al. } \\
1997\end{array}$ & $\begin{array}{l}\text { Provides a classification of techniques for appraising IT investments and develops a taxonomy of direct and indirect } \\
\text { costs that need to be considered when appraising IT investments }\end{array}$ & Review & $\begin{array}{l}\text { Implementation } \\
\text { cost (direct \& } \\
\text { indirect) }\end{array}$ \\
\hline $\begin{array}{l}\text { Irani and } \\
\text { Love } \\
2001 / 2001\end{array}$ & $\begin{array}{l}\text { Describes a case study of a failed and then a second successful implementation of a production planning and control } \\
\text { system. Among the factors identified as contributing to the failure of the system were intangibles such as staff } \\
\text { resistance to implementation, the poor alignment between the selected technology and the existing organizational } \\
\text { processes, and poor project leadership. }\end{array}$ & Case study & $\begin{array}{l}\text { Implementation } \\
\text { cost (direct and } \\
\text { indirect costs) }\end{array}$ \\
\hline $\begin{array}{l}\text { Klemperer } \\
1987\end{array}$ & $\begin{array}{l}\text { Identifies different types of switching costs, including learning costs, transaction costs and artificial costs, and } \\
\text { suggests that policies to increase standardization and reduce switching costs may be beneficial for adopters. }\end{array}$ & Model & Switching cost \\
\hline
\end{tabular}




\begin{tabular}{|c|c|c|c|}
\hline $\begin{array}{l}\text { Klemperer } \\
1995\end{array}$ & $\begin{array}{l}\text { Examines switching costs in markets in which 'brand loyalty' potentially plays a role in determining customer choice. } \\
\text { Looks at the trade off between reducing price to increase market share and charging a high price to harvest profits and } \\
\text { the risks of these strategies. }\end{array}$ & Model & Switching cost \\
\hline $\begin{array}{lr}\text { Kumar } & \text { and } \\
\text { van } & \text { Dissel } \\
1996 & \\
\end{array}$ & $\begin{array}{l}\text { Develops a typology of interorganizational information systems and links this typology to the risks inherent to } \\
\text { stakeholders in each type of system. }\end{array}$ & Theory & Cost of capital \\
\hline Markus 2000 & $\begin{array}{l}\text { Develops a typology of IT risks. Identifies different types of risk associated with IT investments, including (i) } \\
\text { financial; (ii) technical; (iii) project; (iv) political; (v) security; and (vi) incompatibility risks. Also suggests that risks } \\
\text { to competitiveness of acquiring organization may arise if customers or other stakeholders object to the acquired } \\
\text { technology. }\end{array}$ & Theory & Cost of capital \\
\hline $\begin{array}{ll}\text { Mata } & \text { et } \\
1995 & \end{array}$ & $\begin{array}{l}\text { Examines the extent to which sustainable competitive advantage can be achieved as a consequence of IT investment, } \\
\text { using resource-based view (RBV) as lens. Suggests that sustainable competitive advantage is achieved through the } \\
\text { development of IT management skills and not through technical skills or the features of the technology itself. Points to } \\
\text { technological uncertainty and market uncertainty (reputational and competitive) as sources of risk that need to be } \\
\text { factored into the cost of capital. }\end{array}$ & Theory & Cost of capital \\
\hline $\begin{array}{l}\text { McFarlan } \\
1981\end{array}$ & $\begin{array}{l}\text { Examines the risks involved in information systems projects, including financial, technical, project and } \\
\text { incompatibility risks. The study explains how the risks can be assessed for each project and how an aggregate risk } \\
\text { profile can be developed. }\end{array}$ & Theory & Capital costs \\
\hline Meier 1995 & $\begin{array}{l}\text { Develops a framework to assess the importance of relationship management in the use of different types of } \\
\text { interorganizational information system. Suggests that trust is a key component in the successful implementation of } \\
\text { interorganizational information systems. }\end{array}$ & Theory & $\begin{array}{l}\text { Relational cost } \\
\text { (trust) }\end{array}$ \\
\hline $\begin{array}{l}\text { Nakayama } \\
2000\end{array}$ & $\begin{array}{l}\text { Examines the adoption of EDI by grocery wholesalers. The study examines the relationships between the use of EDI } \\
\text { and a suppliers' incentives for EDI use, a wholesalers' perceived bargaining power, and the trust and cooperation } \\
\text { between wholesalers and suppliers. The study finds that the provision of price incentives to support trust among } \\
\text { supply network members positively influences the EDI adoption. }\end{array}$ & Survey & $\begin{array}{l}\text { Relational cost } \\
\text { (trust) }\end{array}$ \\
\hline $\begin{array}{l}\text { Premkumar et } \\
\text { al. } 1994\end{array}$ & $\begin{array}{l}\text { Looks at the adoption of EDI and examines the relationship between innovation characteristics and diffusion. Among } \\
\text { the findings is the fact that cost plays a part in determining adaptation (initial use of the technology). }\end{array}$ & Survey & $\begin{array}{l}\text { Implementation } \\
\text { cost (direct and } \\
\text { indirect costs) }\end{array}$ \\
\hline $\begin{array}{l}\text { Ryan and } \\
\text { Harrison }\end{array}$ & $\begin{array}{l}\text { Examines the changes in social sub-systems that influence indirect costs in IT investments. The results show that } \\
\text { consideration of indirect social costs is infrequently factored into organizational investment decisions. The authors }\end{array}$ & Interviews & $\begin{array}{l}\text { Implementation } \\
\text { cost } \quad \text { indirect }\end{array}$ \\
\hline
\end{tabular}




\begin{tabular}{|c|c|c|c|}
\hline 2000 & $\begin{array}{l}\text { provide a decision tree of factors related to social systems that should be considered for information technology } \\
\text { investment decisions. }\end{array}$ & & costs) \\
\hline $\begin{array}{l}\text { Smith et al. } \\
2001\end{array}$ & $\begin{array}{l}\text { Examines the risks associated with the use of information systems and identifies risks under the broad headings of } \\
\text { financial, technology, people, security, information, business process, management and external risks and the risks of } \\
\text { success. Suggests ways of assessing and dealing with risk. }\end{array}$ & Case study & Cost of capital \\
\hline $\begin{array}{l}\text { Soliman and } \\
\text { Janz } 2004\end{array}$ & $\begin{array}{l}\text { Examines the factors that determine the adoption of Internet-based interorganizational information systems, including } \\
\text { pressures felt from trading partners, pressure felt from competitors, establishment costs (in terms of cost savings } \\
\text { realised by implementing Internet-based solutions), network reliability, data security, scalability, complexity, support } \\
\text { from top management, and trust between trading partners. The study finds that concerns about poor network reliability } \\
\text { and data security and the existence of trust between trading partners influence the decision to adopt. }\end{array}$ & Survey & $\begin{array}{l}\text { Cost of capital } \\
\text { Relational costs }\end{array}$ \\
\hline Sumner 2000 & $\begin{array}{l}\text { Examines the risk factors in implementing enterprise-wide systems. The paper identifies risks around organizational } \\
\text { fit, failure to adjust the skill mix required, failures in management structure and strategy, inappropriate software } \\
\text { design, inadequate user involvement and training, and problems in linking to legacy systems. }\end{array}$ & Case study & Cost of capital \\
\hline $\begin{array}{l}\text { Tang and } \\
\text { Zannetos } \\
1992\end{array}$ & $\begin{array}{l}\text { Examines how the likelihood of adoption of process innovations is determined by incumbent technologies and } \\
\text { suggests that organizations may decide to choose incremental improvement of existing technologies, even when the } \\
\text { improved technology gives lower efficiencies than switching to a new technology. }\end{array}$ & Model & Switching costs \\
\hline $\begin{array}{l}\text { Zhu et al. } \\
2006\end{array}$ & $\begin{array}{l}\text { A study of open standards interorganizational information systems adoption finds that costs (including financial costs, } \\
\text { managerial complexity, transactional risks and legal barriers) act as a significant barrier to adoption, but for } \\
\text { organizations that have adopted EDI the costs act as a greater barrier. The study also discusses switching costs and } \\
\text { finds that existing investments in EDI acted as a deterrent to the adoption of open standards interorganizational } \\
\text { information systems because the two types of systems were deemed incompatible. }\end{array}$ & Survey & $\begin{array}{l}\text { Switching costs } \\
\text { Implementation } \\
\text { costs (direct } \\
\text { and indirect) }\end{array}$ \\
\hline
\end{tabular}


Table 3. Organizational innovation stages

\begin{tabular}{|c|c|c|c|c|c|}
\hline Author(s) & $\begin{array}{l}\text { Thompson } \\
\text { (1965) }\end{array}$ & $\begin{array}{l}\text { Rogers } \\
(\mathbf{1 9 9 5}) \\
\end{array}$ & $\begin{array}{l}\text { Meyer and } \\
\text { Goes (1988) }\end{array}$ & $\begin{array}{l}\text { Utterback } \\
(\mathbf{1 9 7 1}) \\
\end{array}$ & $\begin{array}{l}\text { Zmud \& } \\
\text { colleagues }\end{array}$ \\
\hline \multirow[t]{2}{*}{$\begin{array}{l}\text { Innovation } \\
\text { Type }\end{array}$} & $\begin{array}{l}\text { Organizational } \\
\text { innovation }\end{array}$ & $\begin{array}{l}\text { Any } \\
\text { innovation }\end{array}$ & $\begin{array}{l}\text { Medical } \\
\text { innovation }\end{array}$ & $\begin{array}{l}\text { Product and } \\
\text { process / } \\
\text { technical } \\
\text { innovation }\end{array}$ & $\begin{array}{l}\text { Information } \\
\text { systems } \\
\text { innovation }\end{array}$ \\
\hline & Generation & $\begin{array}{l}\text { Agenda } \\
\text { setting }\end{array}$ & $\begin{array}{l}\text { Knowledge } \\
\text { awareness }\end{array}$ & Idea generation & Initiation \\
\hline \multirow[t]{5}{*}{ Stages } & Acceptance & Matching & $\begin{array}{l}\text { Evaluation - } \\
\text { choice }\end{array}$ & Problem solving & Adoption \\
\hline & \multirow{4}{*}{ Implementation } & $\begin{array}{l}\text { Redefining / } \\
\text { restructuring }\end{array}$ & \multirow{4}{*}{$\begin{array}{l}\text { Adoption - } \\
\text { implementation }\end{array}$} & \multirow{4}{*}{ Implementation } & Adaptation \\
\hline & & Clarifying & & & Acceptance \\
\hline & & Routinizing & & & Routinization \\
\hline & & & & & Infusion \\
\hline
\end{tabular}


Table 4. Categories of interorganizational process innovation adoption costs in supply networks

\begin{tabular}{|c|c|c|c|}
\hline Stage & Types of Cost & Examples & \multirow{2}{*}{$\begin{array}{l}\text { Selected studies } \\
\text { Pisano } 1997\end{array}$} \\
\hline \multirow{3}{*}{ 焉 } & \multirow{2}{*}{$\begin{array}{l}\text { DEVELOPMENT COSTS (for } \\
\text { developers): costs associated } \\
\text { with participation in the } \\
\text { elaboration of a new technology }\end{array}$} & $\begin{array}{l}\text { Internal costs: internal research and } \\
\text { development costs involved in in-house } \\
\text { development. }\end{array}$ & \\
\hline & & $\begin{array}{l}\text { External costs: participation and negotiation } \\
\text { costs associated with the involvement in } \\
\text { collaborative arrangements. }\end{array}$ & $\begin{array}{l}\text { Antonelli 1994; } \\
\text { Foray 1994; Gupta } \\
\text { et al. } 2008\end{array}$ \\
\hline & $\begin{array}{l}\text { INITIATION COSTS (for } \\
\text { acquirers): costs associated with } \\
\text { building awareness about a new } \\
\text { innovation }\end{array}$ & Awareness buildings costs & \\
\hline \multirow[b]{3}{*}{ 岳 } & \multirow{2}{*}{$\begin{array}{l}\text { SWITCHING COSTS: } \\
\text { compatibility costs arising from } \\
\text { the need for compatibility with } \\
\text { existing assets when changing } \\
\text { from an existing technology to a } \\
\text { new technology }\end{array}$} & $\begin{array}{l}\text { Technological compatibility costs: } \\
\text { complementary technological resources, e.g. } \\
\text { costs associated with incumbent software and } \\
\text { hardware. }\end{array}$ & \multirow[t]{2}{*}{$\begin{array}{l}\text { Klemperer } \\
\text { 1987;1995; Zhu et } \\
\text { al. 2006; Forman } \\
\text { 2005; Powell and } \\
\text { Dent-Micallef } 1997\end{array}$} \\
\hline & & $\begin{array}{l}\text { Organizational compatibility costs: } \\
\text { complementary organizational resources, e.g. } \\
\text { changing the existing capabilities in } \\
\text { marketing, service or distribution. }\end{array}$ & \\
\hline & $\begin{array}{l}\text { COST OF CAPITAL: costs } \\
\text { associated with the uncertainty } \\
\text { of investment in innovation }\end{array}$ & $\begin{array}{l}\text { Costs associated with technology } \\
\text { uncertainties } \\
\text { - Financial risk: the costs incurred fail to } \\
\text { deliver the projected benefits either } \\
\text { because benefits were overestimated } \\
\text { and/or costs were underestimated. } \\
\text { - Technical risk: the delivered technical } \\
\text { performance is below what was } \\
\text { anticipated, and results from a a } \\
\text { technology being immature, poorly } \\
\text { understood, unreliable, obsolete or } \\
\text { unstable. } \\
\text { Project risk: ineffective and/or inefficient } \\
\text { project delivery resulting from lack of } \\
\text { appropriate skills and expertise to deal } \\
\text { with the technological complexity, longer } \\
\text { than anticipated implementation time, } \\
\text { and/or a high turnover of key personnel. } \\
\text { Political risk: situations in which a } \\
\text { technology adoption project and/or the } \\
\text { technology itself is subjected to } \\
\text { organizational political infighting or } \\
\text { resistance. } \\
\text { - Security risk: the inability of an } \\
\text { organization and its exchange parties to } \\
\text { trust the information technology } \\
\text { environment. Includes contingency risk } \\
\text { associated with accidents, disasters and } \\
\text { viruses; the risk of non-use, under-use or } \\
\text { misuse of the technology by the intended } \\
\end{array}$ & $\begin{array}{ll}\text { Clemons } & 1991 ; \\
\text { McFarlan } & 1981 ; \\
\text { Markus } & 2000 ; \\
\text { Smith } \text { et al. } & 2001 ; \\
\text { Sumner 2000 }\end{array}$ \\
\hline
\end{tabular}




\begin{tabular}{|c|c|c|c|}
\hline & & $\begin{array}{l}\text { users; abuse of the system by users } \\
\text { within the adopting organization, } \\
\text { including the potential for sabotage and } \\
\text { malicious destruction; and the possibility } \\
\text { of destruction of, or damage to, the } \\
\text { system by those outside the organization. } \\
\text { - Incompatibility risk: the developed } \\
\text { technology is incompatible with existing } \\
\text { hardware and software and with user } \\
\text { wants. It results from poor understanding } \\
\text { of the project brief or client needs, and } \\
\text { fundamental changes in the adoption } \\
\text { environment that render the } \\
\text { functionalities embodied in the } \\
\text { technology obsolete or inappropriate on } \\
\text { completion of the project. }\end{array}$ & \\
\hline & & $\begin{array}{l}\text { Costs associated with market uncertainties } \\
\text { - Competitive risks: negative reactions by } \\
\text { customers, competitors and/or } \\
\text { technology suppliers. } \\
\text { - Reputational risks: potential negative } \\
\text { reactions by the general public, the } \\
\text { media, government or other potential } \\
\text { stakeholders. }\end{array}$ & Markus 2000 \\
\hline \multirow[t]{2}{*}{ 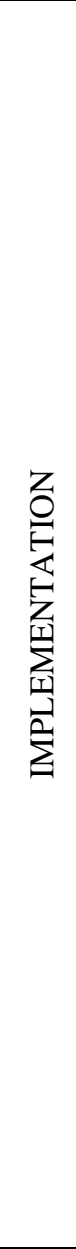 } & \multirow[t]{2}{*}{$\begin{array}{l}\text { IMPLEMENTATION COSTS: } \\
\text { the costs associated with } \\
\text { acquiring and implementing an } \\
\text { interorganizational process } \\
\text { innovation }\end{array}$} & $\begin{array}{l}\text { Direct technology costs } \\
\text { - Initial user specification of the system } \\
\text { including initial hardware, software and } \\
\text { installation costs; and installation and } \\
\text { configuration costs, which include } \\
\text { consultancy support, installation } \\
\text { engineers and networking hardware and } \\
\text { software } \\
\text { - Unexpected hardware and software costs } \\
\text { including increased processor power and } \\
\text { software upgrades } \\
\text { - Other sources of direct costs including } \\
\text { security costs to ensure protection against } \\
\text { viruses and abuse of the technology; } \\
\text { system development costs, including the } \\
\text { time spent customising a system; } \\
\text { environmental operating costs to include, } \\
\text { for example, the power required to run } \\
\text { the system; and maintenance costs such } \\
\text { as yearly service contracts }\end{array}$ & $\begin{array}{l}\text { Irani et al. 1997; } \\
\text { Irani and Love } \\
2000 / 2001 ; \\
\text { Baldwin and Lin } \\
2002\end{array}$ \\
\hline & & \begin{tabular}{|l} 
Indirect social costs \\
$-\quad$ Organizational costs: losses in \\
organizational productivity; strains on \\
organizational resources; business \\
process reengineering; organizational \\
restructuring \\
- Human costs: the time and resources \\
expended by managers and operators in \\
getting the system to work; systems
\end{tabular} & $\begin{array}{l}\text { Fitzgerald 1998; } \\
\text { Irani et al. 1997; } \\
\text { Irani and Love } \\
\text { 2000/2001; Ryan } \\
\text { and Harrison 2000; } \\
\text { Baldwin and Lin } \\
\text { 2002; Chau and } \\
\text { Tam 1997 }\end{array}$ \\
\hline
\end{tabular}




\begin{tabular}{l|l|l|l}
\hline & $\begin{array}{l}\text { support activities; training costs; changes } \\
\text { in salaries (such as pay increases based } \\
\text { on improved employee flexibility); and } \\
\text { the resources required to deal with the } \\
\text { consequences of staff turnover }\end{array}$ & \\
& & & \\
& & & \\
\cline { 2 - 5 } & $\begin{array}{l}\text { RELATIONAL COSTS: costs } \\
\text { associated with the relational } \\
\text { context in which the innovation } \\
\text { is implemented }\end{array}$ & $\begin{array}{l}\text { Cost associated with lack of trust between } \\
\text { supply network partners leading to inl } \\
\text { feelings, resentment, tension, conflicts and } \\
\text { withdrawal between innovation adopters. }\end{array}$ & $\begin{array}{l}\text { Allen } \text { Ge al. 2000; } \\
\text { Gerst } \\
\text { Bunduchi 2005b }\end{array}$ \\
\hline
\end{tabular}

